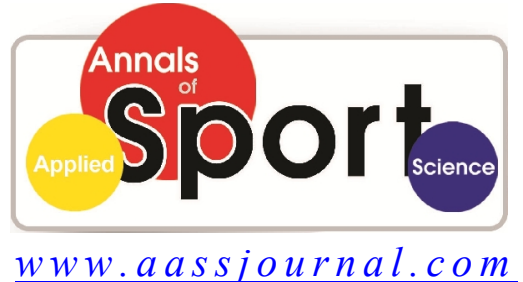

ISSN (Online): $2322-4479$

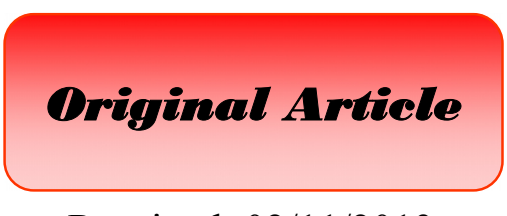

Received: 02/11/2013

Accepted: 20/02/2014

\title{
Validity and Reliability of Sport Organizational Citizenship Behavior Questionnaire
}

\section{${ }^{1}$ Hamid Sarani* ${ }^{2}$ Ali Mohammad Safania}

1. Faculty of Physical Education and Sports Sciences, International Campus, Kharazmi University, Karaj, Iran.

2. Department of Physical Education and Sports Sciences, Science and Research Campus, Islamic Azad University, Tehran, Iran.

\begin{abstract}
This research has been designed and conducted to evaluate the validity and reliability of organizational citizenship behavior questionnaire as an instrument in sports environment to assess the status of organizational citizenship behavior dimensions among the athletes of clubs. A 20-question questionnaire has been designed to measure the dimensions of organizational citizenship behavior by studying the background of existing researches and questionnaires. The statistical sample included all of male athletes working in Iran's Futsal premier league, and 144 questionnaires returned at last. In this research, the exploratory and confirmatory factor analysis was used to evaluate the validity of structure after assessing the validity of content and convergent validity (average variance extracted). And, to evaluate the combinational reliability, Cronbach's Alpha was used. Moreover, the applications SPSS and PLS-Graph were used to analyze data. The results of exploratory factor analysis indicated that five factors were explained by $69.10 \%$ of variance, and Kaiser-Meyer-Olkin was measured $85.5 \%$. The reliability of the questionnaire was reported to be $91 \%$ and $93 \%$ based on Cronbach's Alpha and combinational reliability, respectively. Given the fact that the validity and reliability indexes of questionnaire have all been reported to be in a satisfactory condition, this questionnaire can be used as a valid and reliable questionnaire to measure organizational citizenship behavior and its dimensions .
\end{abstract}

Key Words: Organizational Citizenship Behavior in Sports, Standardization, Validity, Reliability.

Corresponding Author:

Hamid Sarani

E-mail: hamid.sarani1@gmail.com 


\section{INTRODUCTION}

The concept of organizational citizenship behavior, abbreviated as OCB, was presented to the science world for the first time by Bateman and Organ in the early 1980s. The initial researches which were carried out regarding OCB were mostly meant for identifying responsibilities and behaviors showed by the staff but often overlooked. Although these behaviors were partially measured in traditional evaluations of job performance or even often neglected, they were effective on improving organizational efficiency (1). These affairs, which happen in the workplace, are defined as follow: a set of voluntary and optional behaviors which are not a part of the individual's official duties, although they are done by the individual, improving the roles and duties of the organization effectively (2).

Organ also believes that the organizational citizenship behavior is the individual, voluntary behavior which is not directly designed by the official rewarding systems in the organization, although it elevates the efficiency and performance of the organization (3). Studies conducted on OCB mainly fall into three types:

A group of studies has been focused on predicting the factors creating organizational citizenship behaviors. In this field, factors like job satisfaction, organizational commitment, organizational identity, organizational fairness, trust, types of leadership, and the relationship of leader and follower have been mentioned as factors creating organizational citizenship behaviors (4).

On the other hand, some of the researches have been focused on the outcomes of organizational citizenship behaviors. In this field, factors like organizational performance, organizational efficiency, organizational success, customer's satisfaction, customer's loyalty, and social capital have been mentioned (4, 5).

A group of researches has exclusively been focused on the concept of OCB. They have tried to present a new definition of it, to clarify its dimensions, and to create standard scales for the evaluation of this concept with the help of factor analysis method $(4,6)$.

Given the current vacuity and the increasing need of clubs to know the athletes completely and the dependency of clubs' policies and executive approaches success on human capital, we have decided to create and standardize the a questionnaire regarding sports OCB in a cross-sectional study by reviewing Organ's and Podsakoff's OCB questionnaires and choosing and designing questions special for sports environment.

\section{MATERIALS AND METHODS}

This research is of analytical-sectional type.

Participants. The statistical population of this research consists of all male athletes working in Iranian Futsal premier league in season 2012, containing 175 people. The sample was considered equal to the population, and 144 questionnaires were returned after sending them to the designated teams. Choosing the sport of Futsal was because of the fact that it attracts more and more aficionados due to popularity and facilitation of investments and provisions (7).

Instruments. After reviewing OCB literature and available questionnaires, 20 questions were designed to measure sports OCB and its dimensions. 4 questions evaluate the philanthropy dimension; 3 ones assess work ethics; 4 ones evaluate chivalry; 4 ones relate to civic virtue; and 5 ones evaluate modesty and courtesy. The sum of 
these five dimensions defines the sports OCB score. Each question has been valued by 5 -score Likert's scale from 1 (completely disagree) to 5 (completely agree). The entire band score of the questionnaire varies from 19 to 95 , stating that a higher score would suggest a better sportive OCB. After sending the questionnaire to 10 teachers of sportive management, only one question of work ethics dimension was left out due to the inferiority of content validity (less than $60 \%$ ). Finally, 19 questions were designated for the evaluation of sportive OCB variable.

Protocol. In this study, the samples answered demographic questions regarding age, record of membership in the club, and marital status as well as the questions of OCB questionnaire (The questionnaire is placed at the end of appendix A.). In this research, content validity and convergent validity (average variance extracted) were used to evaluate the validity.

Statistical Analysis. The exploratoryconfirmatory factor analysis was used to evaluate the structure validity; combinational reliability and Cronbach's Alpha were used to assess the reliability; and SPSS and PLS-Graph were used to analyze the data.

\section{RESULTS}

The average age of Futsal players is 24.87 years and the average record of membership in the respective club is 3.18 . $81.3 \%$ of the players were single and $18.7 \%$ of them were married.

Several methods were used to evaluate the validity of questionnaire. At first and after designing, the questionnaire was sent to 10 scholars of sport management and their final viewpoints on content validity and reliability (CVR) of the questionnaire was asked, and all the questions scored over than $60 \%$ except for one questions (left out of the process of calculations.). Also, the average variance extracted (AVE) was calculated through using the software PLSGraph (table 1). The index of average variance extracted is advised to be 0.4 and more by the researchers (8).

Table 1 - Average variances extracted for the latent variables of the research

\begin{tabular}{cc}
\hline Average variance extracted & The latent variable \\
\hline Philanthropy & 0.641 \\
\hline Work ethics & 0.786 \\
\hline Chivalry & 0.556 \\
\hline Civic virtue & 0.601 \\
\hline Modesty and courtesy & 0.719 \\
\hline Sportive OCB & 0.458 \\
\hline
\end{tabular}

Two methods of exploratory and confirmatory factor analyses have been used in order to evaluate the structure validity and determining the entries of the questionnaire. The exploratory factor analysis was applied through using principal component analysis method with Promax rotation in order to check the adaptability degree and nominating extracted factors. Using the entire observations $(n=144)$, the factor analysis resulted in identifying 5 factors with the variance explanation of $69.79 \%$ and Kaiser - Meyer - Olkin index of 88.4\% both considered to be good factor analysis indexes. After conducting the exploratory factor analysis with the use of loaded amounts on the questions, the extracted factors were nominated. These five names included philanthropy, work ethics, chivalry, civic virtue, and modesty and courtesy. The percentages of variances 
relating to factor analysis matrix and their rotations have been shown in table 2 , and factor weights and nominations of five factors extracted through the exploratory factor analysis have been shown in table 3.

Table 2 - Total Variance Explained

\begin{tabular}{cccc|ccc}
\multirow{2}{*}{ Component } & \multicolumn{3}{c|}{ Extraction Sums of Squared Loading } & \multicolumn{3}{c}{ Rotation Sums of Squared Loading } \\
\cline { 2 - 7 } & Total & \% of Variance & Cumulative \% & Total & \% of Variance & Cumulative \% \\
\hline 1 & 8.140 & 42.844 & 42.844 & 3.895 & 20.503 & 20.503 \\
\hline 2 & 1.659 & 8.732 & 51.577 & 3.055 & 16.079 & 36.581 \\
\hline 3 & 1.338 & 7.041 & 58.617 & 2.346 & 12.345 & 48.926 \\
\hline 4 & 1.100 & 5.788 & 64.406 & 2.203 & 11.596 & 60.523 \\
\hline 5 & 1.022 & 5.380 & 69.786 & 1.760 & 9.263 & 69.786 \\
\hline
\end{tabular}

Table 3 - The weights of factors extracted from exploratory factor analysis with matrix rotation

\begin{tabular}{|c|c|c|c|c|c|}
\hline \multirow[b]{2}{*}{ Question } & \multicolumn{5}{|c|}{ Component } \\
\hline & Philanthropy & $\begin{array}{l}\text { Work } \\
\text { Ethics }\end{array}$ & Chivalry & $\begin{array}{l}\text { Civic } \\
\text { Virtue }\end{array}$ & $\begin{array}{c}\text { Modesty } \\
\text { and } \\
\text { Courtesy }\end{array}$ \\
\hline My teammate doesn't abuse others' rights. & 0.784 & & & & \\
\hline $\begin{array}{l}\text { My teammate avoids causing problems for co- } \\
\text { players. }\end{array}$ & 0.664 & & & & \\
\hline $\begin{array}{l}\text { My teammate considers the effects of his } \\
\text { actions on others' performance. }\end{array}$ & 0.527 & & & & \\
\hline $\begin{array}{l}\text { My teammate doesn't need continual } \\
\text { surveillance. }\end{array}$ & 0.523 & & & & \\
\hline $\begin{array}{l}\text { My teammate avoids having problems with } \\
\text { other players. }\end{array}$ & & 0.84 & & & \\
\hline $\begin{array}{l}\text { My teammate is aware of how his behavior } \\
\text { affects others' performances. }\end{array}$ & & 0.787 & & & \\
\hline $\begin{array}{l}\text { My teammate doesn't spend much time } \\
\text { complaining about trivial matters. }\end{array}$ & & & 0.517 & & \\
\hline My teammate considers the team integrated. & & & 0.678 & & \\
\hline My teammate avoids violations. & & & 0.607 & & \\
\hline $\begin{array}{l}\text { My teammate doesn't try to find errors in } \\
\text { team's performance. }\end{array}$ & & & 0.735 & & \\
\hline $\begin{array}{l}\text { My teammate participates in important } \\
\text { meetings which aren't necessary. }\end{array}$ & & & & 0.815 & \\
\hline $\begin{array}{l}\text { My teammate does the unnecessary tasks } \\
\text { indicating a positive image of the team. }\end{array}$ & & & & 0.735 & \\
\hline $\begin{array}{l}\text { My teammate's attendance in team and } \\
\text { exercises is beyond expectation. }\end{array}$ & & & & 0.66 & \\
\hline My teammate helps make changes in the team. & & & & 0.572 & \\
\hline $\begin{array}{l}\text { My teammate helps those who were absent in } \\
\text { exercise sessions. }\end{array}$ & & & & & 0.748 \\
\hline $\begin{array}{l}\text { My teammate helps those who bear heavy } \\
\text { responsibility in the team }\end{array}$ & & & & & 0.655 \\
\hline My teammate helps newcomers in the team. & & & & & 0.825 \\
\hline $\begin{array}{l}\text { My teammate eagerly helps those who have } \\
\text { job-related problems. }\end{array}$ & & & & & 0.801 \\
\hline $\begin{array}{l}\text { My teammate is always ready to help players } \\
\text { around him. }\end{array}$ & & & & & 0.711 \\
\hline
\end{tabular}

Sarani, H., and Safania, A. M. (2014). Ann Appl Sport Sci, 2(2): 101-108. 
After the exploratory factor analysis, we conducted the confirmatory factor analysis for each of dimensions of sportive OCB by using the software PLS-Grapgh.

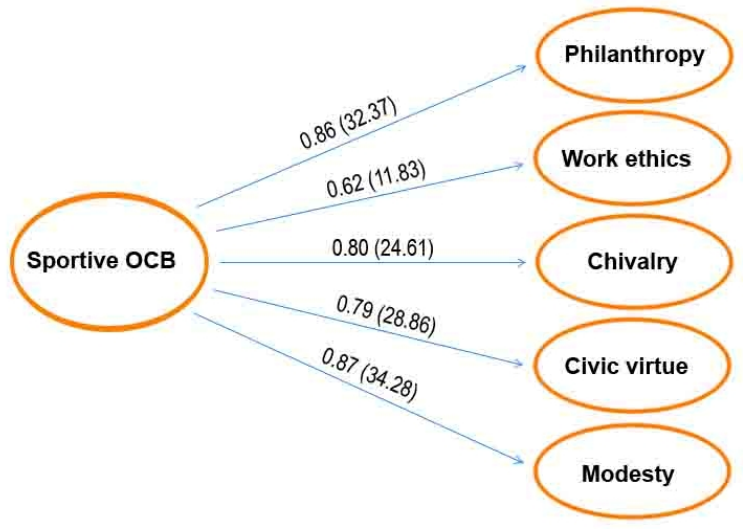

Figure 1. Confirmatory factor analysis. The numbers inside parentheses above each axis indicate the significance, and the numbers outside parentheses show the coefficient of each component's effect with sportive OCB.

The combinational validity method and internal correlation method (Cronbach's Alpha) have been used to measure the validity. The amount of validity for components of philanthropy, work ethic, chivalry, civic virtue, and modesty and courtesy were calculated as $0.887,0.88$, $0.833,0.857$, and 0.927 , respectively. This amount has been calculated as 0.933 for the entire questionnaire. The coefficient of greater than 0.6 for combinational validity for each construct suggests the appropriate validity (8). Also, Cronbach's Alpha has respectively been calculated $0.812,0.733$, $0.735,0.772,0.901$, and 0.924 for the entire questionnaire.

\section{DISCUSSION and CONCLUSION}

The sportive increasing importance and attractions have all caused more attention toward championship athletic in nowadays modern world. These attentions are more observed in modern world of sports to an extent which many supportive plans are presented for athletes, coaches, and all the practitioners of this field to achieve championship. These plans are different in terms of countries' conditions and sports fields. Nowadays, sport is an industry, and it's necessary to provide more resources for greater and rapid success. This cannot be achieved unless by creating an appropriate sportive structure. Undoubtedly, achieving high positions in different sports fields needs planning and developing human resources especially at management level. Most of managers desire employees who work more than what is declared in their job descriptions. They seek employees who go beyond expectations, eagerly take up behaviors which are not included as their official tasks, and generally have high OCB. Such behaviors (role model and meta-role model) are partly affected by features and traits of employees and their willingness to do such tasks. In this regard, it seems that the employees who are generally more satisfied with their conditions will show more organizational citizenship behaviors as a result (7). The term of organizational citizenship was first stated by Organ et al. in 1983. The development of this concept has been caused by Kots' and Kons' studies on spontaneous and innovative behaviors and performances in 1964 and 1978 (9).

There hasn't been any unanimous agreement regarding the dimensions of OCB amongst the researchers. Podsakoff et al. (2000) indicated that almost 30 different kinds of OCB dimensions overlapping much in concept had been identified (4). Yet, five dimensions which have been more agreed upon by the researchers and used in this paper are as follows (10):

1. Work Ethics: meaning doing the internal role behaviors more than the minimally required task,

2. Philanthropy: helping others/coworkers, 
3. Civic Virtue (behavior): cooperation in the political lifecycle of organization,

4. Chivalry: tendency for bearing the avoidably distressing working conditions,

5. Modesty and Courtesy: meaning acting respectfully toward others.

Since sports team, like other organizations, need responsible members to encounter environmental challenges and competitions, and considering the roles and tasks of sports teams' players, it seems that OCB bears high importance in clubs. Also, the questionnaire made for OCB had a high validity index. Therefore, according to the findings and the advantages of this questionnaire including the small number of questions and considering five components agreed upon by the majority of researchers and its special design for measuring athletes' OCB and its high validity and reliability, using this tool as a proper questionnaire in measuring OCB can be suggested in sports environments. Of the strength points of this study, we can point to the usage of different methods of validity and reliability, calculation of content validity, exploratory and confirmatory factor analysis, and homogeneity of studied population. On the other hand and of the weak points, we can point to the lack of different sampling populations.

\section{REFFRENCES}

1. Bienstock CC, DeMoranville CW, Smith RK. Organizational citizenship behavior and service quality. journal of services marketing. 2003;17(4):357-78.

2. Appelbaum S, Bartolomucci N, Beaumier E, Boulanger J, Corrigan R, Dore I, et al. Organizational citizenship behavior: a case study of culture, leadership and trust. Management decision. 2004;42(1):13-40.

3. Cohen A, Kol Y. Professionalism and organizational citizenship behavior: An empirical examination among Israeli nurses. Journal of managerial psychology. 2004;19(4):386-405.

4. Podsakoff PM, MacKenzie SB, Paine JB, Bachrach DG. Organizational Citizenship Behaviors: A Critical Review of the Theoretical and Empirical Literature and Suggestions for Future Research. Journal of Management. 2000;26(3):513-63.

5. Morrison EW. Role definitions and organizational citizenship behavior: The importance of the employee's perspective. Academy of management journal. 1994;37(6):1543-67.

6. Van Dyne L, Graham JW, Dienesch RM. Organizational Citizenship Behavior: Construct Redefinition, Measurement, and Validation. Academy of management journal. 1994;37(4):765-802.

7. Sarani H, Safania AM, Razavi MH, editors. Moderating role of job satisfaction in the relationship between organizational justice and behavior in male athletes of Futsal Professional League. Second Regional Conference on Physical Education and Sport Sciences; 2013; Malakan, Iran.: Malakan Branch, Islamic Azad University. [Article in Farsi].

8. Gefen D, Straub D. A practical guide to factorial validity using PLS-Graph: Tutorial and annotated example. Communications of the Association for Information Systems. 2005;16(1):5.

9. Castro CB, Armario EM, Ruiz DM. The influence of employee organizational citizenship behavior on customer loyalty. International journal of Service industry management. 2004;15(1):27-53.

10. Singh U, Srivastava KL. Interpersonal trust and organizational citizenship behavior. Psychol Stud. 2009;54(1):65-76. 
تازههاى علوم كاربردى ورزش

مقاله اصيل

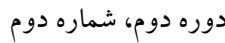

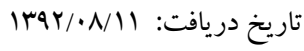

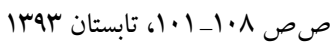

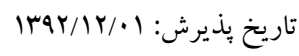

\section{بروسى روايحى و يّايايى ير سشنامه رفتار شهروندى سازمانى توزفى}

\section{'حميد سار انى *' 'على محمد صفانيا}

ا. ا. دانشجوى دكترى مديريت ورزشى، دانشكده تربيتبدنى و علوم ورزشى، يرديس بين الملل، دانشخاه خوارزمى، كرج، ايران.

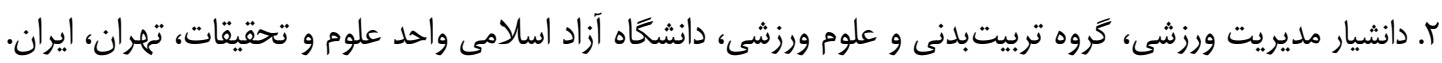

جكيده

اين يُروهش با هدف بررسى روايى و إيايى برسشنامه رفتار شهروندى سازمانى در محيط ورزشى به عنوان ابزارى براى سنجش وضعيت ابعاد

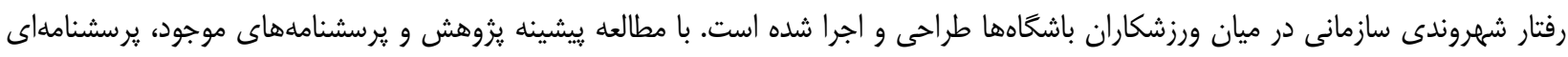

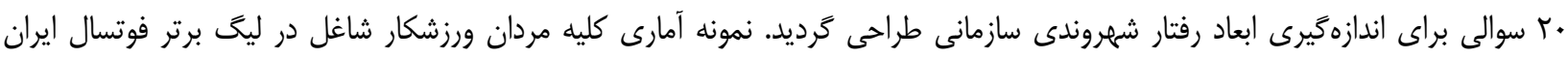

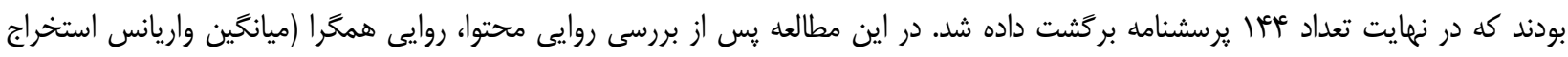

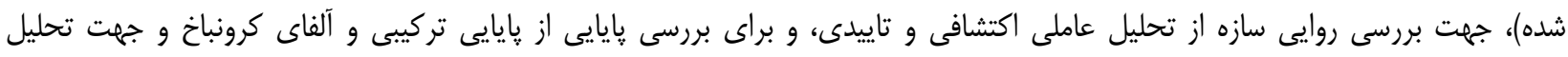

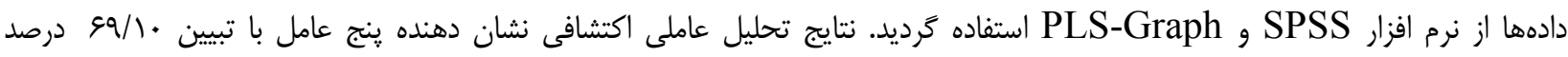

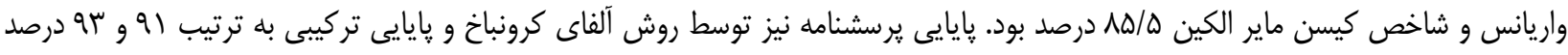

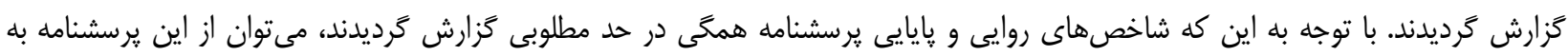

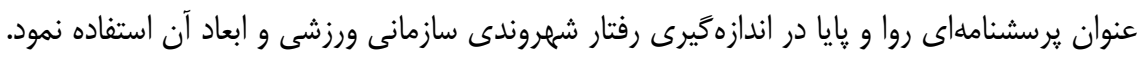
وازكًان كليدى: رفتار شهروندى سازمانى ورزشى، استانداردسازى، روايى، بايايى. 
